\title{
Changes in the Role of Churches and Religious Organizations in the Field of Social Self-Reliance in Hungary (1867-2016)
}

\begin{abstract}
The purpose of this paper is to review the most important trends as found in rendering social services by churches. The typical purposes pursued by religious associations in the era of Dualism and the changes detectable in the activities of the civil sector in Horthy-era were the first examined topics. The paper relies on the empirical research that I conducted in 2014, and that analysed the activities of the largest charity organizations in Hungary. It was possible to conclude that in Hungary there was an exemplary tradition of developing cohesive civic activities in the area of charity. Their efficacy depended on the ability of the organizations to solicit from the donors to help others.
\end{abstract}

Key words: social services, religious organizations, solidarity, charity.

1. I have been conducting my research at the doctoral school of the University of Pécs, Faculty of Law. My research interest is social self-reliance in Hungary since the era of Austro-Hungarian Dualism. This subject is typically not related to churches, but rather to the civil sphere, where it is the citizens who notice social needs, and then formulate and organize activities and organizations to meet such needs. Professionals in the civil sector see this distinction clearly: for them, churches are not part of the civil sphere, so churches are involved in performing social services and are caring for social needs on the basis of separate regulations, different tax legislation, different financing, and remarkably different legal status from the regulations that are applied in the civil sphere.

I have offered to speak here of civil society organizations that are attached to churches, and in this way, are quasi-religious organizations. And secondly, I will be presenting the ways in which churches themselves are involved in performing social services. Since both these topics and the scope of the indicated period are very large, I will limit myself to highlight the major trends in this paper.

Let us see first how various theories relate the church to associations; in other words, what common ground do these two types of organizations share according to the various theories. St. Paul, our earliest author, believed that the Church was an association of 
individuals, a body where all believers become members by being reborn. ${ }^{1}$ In addition to that, according to Paul, the church was a living organism, an active body. John Locke simply believed that church-related communities are the same as secular civil communities: they correspond to each other, even though they have different goals. ${ }^{2}$ Similarly, the Weimar Constitution [ $\S 124]$ discusses religious associations under the heading of the free foundation of associations and partnerships. It is widely accepted that the Church is actually a special association of individuals - and I keep this assumption in mind when I discuss the roles that churches and church-related civil society organizations play in performing social functions.

2. First of all, it is necessary to define what I mean by quasi-religious organizations among civil society organizations. These organizations are also under the civil law in force, ${ }^{3}$ but they form a special group, either because they were founded by clergymen, or because they display a specifically ecclesiastical or religious nature in their objectives. They aim, like the other non-governmental organizations, to reach society, and to fulfil social functions. Their predecessors during both the Era of Reforms and Dualism had the following names: religious societies, denominational societies, devotional societies; ${ }^{4}$ meaning that they were clearly present - and visibly different from civil society organizations - also in the civilian era when a variety of associations proliferated.

Their features have remained the same regardless of whether we take $21^{\text {st }}$-century quasi-religious associations or their predecessors in the end of the $19^{\text {th }}$ century into account. What are these common features and what are the benefits of these features when performing social services? I want to stress that I defined the following features when I examined them in connection to their efficiency in the performance of social services.

One of their special features is that they do not discriminate against members of other religions: they offer their services without taking their own denominations into account, in a non-denominational way. The main reason is that they want to impact society as a whole, thus they make their services accessible to everyone, and they represent their goals before the masses. Secondly, they formulate universal values, which are able to mobilize the masses in favour of their goals. These are clearly Judeo-Christian values, like, for example, taking responsibility for others, charity, selflessness, sacrifice, solidarity. Although one can hear about these values in the communication of civil society organizations too, they aren't formulated in such a strong and consistent manner as in the case of religious organizations. This also shows that these organizations are closely intertwined with the church behind them. Another outstanding feature is that they have a church as their hinterland, that is to say, the founding religious entities are able to mobilize their financial and human resources, and even their international relations, to achieve a social objective. The church as a hinterland also means centuries of experi-

1 Holy Bible, 2 Corinthians 12, 12.

2 G. Halmai, Az egyesülés szabadsága. Az egyesülési jog története [Freedom of Association. The History of Right of Association], Budapest 1990, p. 32.

3 Act CLXXV of 2001, on freedom of associations, public utility, function and support of civil organizations.

4 N. Mondovics, A magyar vallási egyesületek múltjáról [The History of Hungarian Denominational Associations], A. Ádám (ed.), PhD Tanulmányok 13., Pécs 2014, pp. 251-268. 
ence, which is a great advantage, for example, in enrolling volunteers, addressing people, raising funds, cooperating with other organizations. This is also connected to their lobbying power: they have taken part in political decision-making processes, and even in the Board of the National Cooperation Fund set up to finance civil society organizations. ${ }^{5}$ Moreover, when performing certain social services, it is a key feature that the church-as-hinterland implies an institutional system, as well, which makes the services possible even in cases of extremely expensive tasks that quasi-religious organizations have to carry out. A highly expensive social service is, for example, healthcare. Also, let's not forget about the fact that the founders and organizers of the quasi-religious organizations are characterized by faith and belief, that is to say, a higher-than-average commitment to achieve their goals. What is the overall result of these special characteristics? Their overall result is lesser staff turnover among religious organizations; they are not dissolved within a few years; they can be known on a national scale, thanks to their hinterland, the church and the media; and they are stable partners of the State.

In this regard, in the following segment we are going to examine the question of where religious organizations today typically assume their roles. These are the areas of social welfare, education and healthcare, which correspond to the areas where the Church is traditionally present. If we look back at the typical purposes of religious associations in the Era of Dualism, we only see a minor difference. Here, in fact, the earliest and most frequent ones were burial societies, such as the Jewish Chevra Khadisha, which functioned almost like a modern insurance company. In fact, in the event of death, the community bore the responsibility for covering burial costs, for caring for the orphans, but in return, participation in the Chevra Kadisha was compulsory in the form of financial contributions as well as voluntary work. In addition to this, religious societies had general charitable objectives at their core, which was usually revealed by their name. Here, however, one brief digression should be made, because the category of religious association did not appear consistently in the registers of associations. This produced several problems, for a variety of reasons, to define and find them.

One of the main difficulties of the research on associations is the fact that recorded statistics are few and rare $;{ }^{6}$ moreover, the concept of association itself is under-developed ${ }^{7}$ legislation is missing sometimes; and the political milieu is not always supportive. In addition to that, research on religious associations also has its own additional, specific difficulties, such as the fact that a number of religious societies were established by church authorities, and not by the state administration, and thus they were not registered by the Interior Affairs Agency and in county records. The highly valuable and informative materials of Jewish associations, belonging to rural Jewish communities in Hungary, were seized and confiscated by the Gestapo. And by the 1970s, religious associations

5 N. Mondovics, Az önkéntesség és a magánadományozás tíz magyarországi szervezet müködésében [Voluntarism and Philantrophy on Ten Hungarian Organizations], A. Ádám (ed.), PhD Tanulmányok 14., Pécs 2015, pp. 91-118.

6 A. Márfi, Baranya vármegye egyesületei 1867-1914 [Association of Baranya Counties], Pécs 1986, p. 193.

7 I. Sebestény, Az egyesületek számbavételének módszertani problémái a történeti statisztikában [The Methodical Problems of Reviewing Associations in Historical Statistics], "Statisztikai Szemle" 2003, Vol. 4, pp. 373-387. 
completely disappeared, ${ }^{8}$ both from statistics and historiography. And finally, there is the difficulty that religious organizations and groups had centuries-old traditions, so establishing an association was merely one of the possible forms for them to carry out social services, which they used to accomplish using many different methods. This is why one shouldn't overrate the weight or roles played by the religious associations - yet their important work and presence makes it worthwhile to study them. We see that the statisticians of that era recorded the associations according to several typologies; they did not follow the same classifications and labels all the time.

First of all, we see the features of associations in Somogy county. The earliest indication to a denomination in the name of an association is 'Israelite' in the 'Israelite Women's Association of Marcali', as early as in 1869, whereas the first association wearing the 'Christian' label was not established until $1898 .{ }^{9}$ Surely, the Israelites felt more in need to form societies, and were receptive to this form of representation of their interests, because of the ample amount of emergencies they had experienced in their recorded history. Moreover, this era coincides with the age of Jewish assimilation, so the foundation of an association was a means of assimilation for them: this was a way for them to participate in the life of their towns, and to create a range of social contacts, and to counter anti-Semitic prejudices. ${ }^{10}$

Catholic or Protestant associations were only registered after the Jewish associations, sometimes with a delay of several decades. Between 1896 and 1914, however, there was a dynamic growth in the number of Catholic associations: out of 448 associations 61 were Catholic $(13,62 \%)$. As a matter of fact, the Roman Catholic associations were predominantly reading circles - while the faithful Jews and Protestants still preferred charity associations - which is explained by the fact that in this period, the Catholic Church suffered a loss of dominance in public education.

In the Nógrád county registry we see that the use of denominational labels like 'Catholic', 'Christian', or 'Jewish' does not primarily indicate the religious purpose or activity of the organization, but the religious affiliation of its members or supporters. And in their charters, they increasingly tended to emphasize that they helped poor children without taking their religious affiliation into account with, for instance, winter clothes or other charitable deeds. We also see examples when there was a political initiative to establish religious associations: among these, we find the Roman Catholic Reading Society, whose establishment in 1912 was financially supported by the Ministry of Cultural Affairs. The number of religious associations steadily increased in the county: between 1867 and 1874, two religious associations were established, as opposed to the seven associations between 1875 and 1889 , and the sixteen associations between 1890 and 1918. ${ }^{11}$

8 S. Jobb, Egyesületek Magyarországon [Associations in Hungary], "Statisztikai Szemle" 1972, Vol. 12, p. 1226.

9 S. Bősze, ,,Az egyesületi élet a polgári szabadság...”, Somogy megye egyesületei a dualizmus korában [,Association Movement is the Civic Freedom...”, Associations of Somogy County in Dualism], Kaposvár 1997, pp. 5-8.

10 Á. Tóth, Önszervezö polgárok. A pesti egyesületek társadalomtörténete a reformkorban [Self-organizer Citizens. The Social History of Associations of Pest in Hungary before 1848], Budapest 2005, p. 210.

11 G. Brunda, Egyesületek Nógrád Megyében [Associations in Nógrád County], Salgótarján 1993. 
We can see another feature in Baranya County: here, the bishop of Pécs gave the approval to establish denominational associations, but then he left them under the supervision of the city. Religious associations were mainly established for charity purposes, funeral allowance, and sick-relief. And there was a novelty among Catholic associations: reading circles functioned as farmer associations at the same time, combining cultural goals with the protection of the interests of farmers, and allowing them to exchange their experience. $^{12}$

3. When we move on to the post-World War I period, we see that much has changed in the life of associations, partly because of the losses in material wealth and in human lives caused by the war, and, on the other hand, due to the preparations for the new war, and also as a result of the disappearance of civilian ideals. The losses of the war, war invalids, war orphans, and general impoverishment all contributed to the fact that the state felt the need of its social engagement. ${ }^{13}$

The turn of the century, just like the preceding period, was characterized by an increase in the number of Catholic associations. However, there was a difference: in postWorld War I-era, semi-ecclesiastical organizations were created among civil society organizations. In the background of this trend there was the ideological support of Kuno Klebelsberg, Culture Minister, who declared that nationalist cultural policy should not renounce the contribution of traditional churches. The churches understood this, and they created top-to-bottom religious associations with no spontaneity or enthusiasm, so for example in Horthy-era Nógrád county a quarter of the associations were religious ones. In this era, the denominational label in the name of the association does not necessarily refer to the religious affiliation of those who created it, but to the church whose initiative was behind the establishment of the association. This also meant that churches had a greater say in the operation of these organizations.

In addition, they were organized along the lines of the church hierarchy, that is, Catholic associations were merged into an alliance, and the centralized model of the church was adopted to govern them. This organization was the Actio Catholica, established in many countries around the world. ${ }^{14}$ It was also special in the sense that it involved lay people in the work of the religious organization too; in fact, this was its express purpose. Moreover, it had more opportunities, and it also formulated more farreaching goals than simple associations. ${ }^{15}$

After World War II, by 1950 the majority of the associations were eliminated, including religious associations as well, for mainly ideological reasons. Jewish associations had been systematically eradicated back in 1944: they were simply collected from the registries of the Ministry of Interior Affairs and from local registries, in the same way as Jewish citizens were listed. Other religious associations were dissolved after

12 A. Márfi, Baranya vármegye..., pp. 134-135.

13 G. Gyáni, Gy. Kövér, Magyarország társadalomtörténete a reformkortól a második világháborúig [The Social History of Hungary from the Period of Reforms to the $2^{\text {nd }}$ World War], Budapest 2006, p. 233.

14 A. Gianone, Az Actio Catholica karitatív tevékenysége 1945-1948-ban [The Charity Work of Actio Catholica], Gy. Karczub (ed.), Válogatott tanulmányok [Selected Studies], Budapest 2002, pp. 41-60.

$15 \mathrm{~K}$. Doromby, A hivek felelössége az evangélizációért [The Responsibility of Believers in Evangelization], "Vigilia" 1980, Vol. 8, p. 507. 
the war because religious ideology was considered to be outdated, no longer needed in the Communist era. Therefore, in 1970, when national statistics were prepared, there was absolutely no such category as associations, ${ }^{16}$ and we see different terminology as well: instead of associations, there were social organizations, functioning along some approved objectives.

4. After the change of regime, associations whose members considered it to be important to indicate that they were committed to a denomination or a religion, reappeared; and there are also organizations whose representatives and founders explicitly indicate religious purposes, such as the Hungarian Maltese Charity Service - whose founder, priest Imre Kozma, is still in charge of it. The founders, who are members of the clergy, actively participate in the work of quasi-religious associations; they can serve their associations with their network of national and international relations and by means of their scholarly recognition. Moreover, their status in the church makes it more efficient for them to connect their associations to the church. The church as hinterland offers a base for recruiting volunteers and collecting donations as well. These civil society organizations are present, predominantly in the social sphere and education - just like most churches.

In order to depict more accurate picture of the strongest and largest quasi-religious organizations, I relied on the empirical study I conducted in 2014 on 10 organizations in Hungary. Among these 10 organizations, there were the five charity organizations that according to the law - were entitled to receive and distribute charities in times of natural disasters, and to cooperate closely with the government. These five organisations are also members of the Charity Council, that is to say, they are entitled to make decisions referring to the tasks of the Council, and their implementation. ${ }^{17}$ The Charity Council itself was established with the aim to distribute confiscated and nationalized assets for social purposes. Apart from these five member organizations, I also chose the charitable organizations of smaller, 'non-traditional' churches; as well as two organizations which serve mainly educational purposes, in addition to the fact that they were also involved in charitable work. The organizations I studied were not homogeneous; the only thing they have in common is that they are involved in charitable work. They differ in size and organization type, too. As a result of the interviews, I made the following conclusions:

- The large charitable organizations are linked to churches; the only fully civilian association is the Hungarian Red Cross, which belongs to the International Red Cross, first established in Hungary as part of an international treaty, not as an association.

- The heads of the organizations said that they were mutually reinforcing each other with the churches behind them; they also receive moral and material support from the church; and their charitable work is also a way to promote the Church itself. An example to this is the Hungarian Baptist Aid.

16 S. Jobb, Egyesületek Magyarországon..., p. 1226.

17 Act CXXVIII of 2011, 18.§ (2) on disaster recovery. 
- There is a nationwide network behind them, mainly because their volunteers come from the ranks of church members. Such examples include the Charity Service of Pentecostal Faith Church and the Catholic Caritas.

- Their professional leader is a member of the clergy; see the example of the Maltese Charity Service and the Haver Foundation.

- The profile of the church affects the profile of its charitable work, as well; for example, the foundation belonging to Krishna consciousness movement only deals with the distribution of meals.

These statements, however, are not uniformly typical of all organizations, so although the churches have the possibility to mobilize their faithful to charitable work, they are only partially successful.

What are the reasons behind this? When answering this question, it is helpful to consider the two different sets of data that reveal the extent churches are actually supported. One is the mandatory census, and the other is the taxpayers' declaration about $1+1 \%$ of their taxes. It was established in 1997: since then, it has been made possible for the taxpayers to declare which civil society organization and church would receive $1+1 \%$ of their taxes. In other words, if taxpayers want to support the work of their churches, as well as the charitable activities of their churches, they only have to make a declaration about it when submitting their tax declaration, and the tax authorities forward those taxes directly to the churches. The institution itself may be suitable for strengthening the culture of donation, as well as for measuring the support for churches.

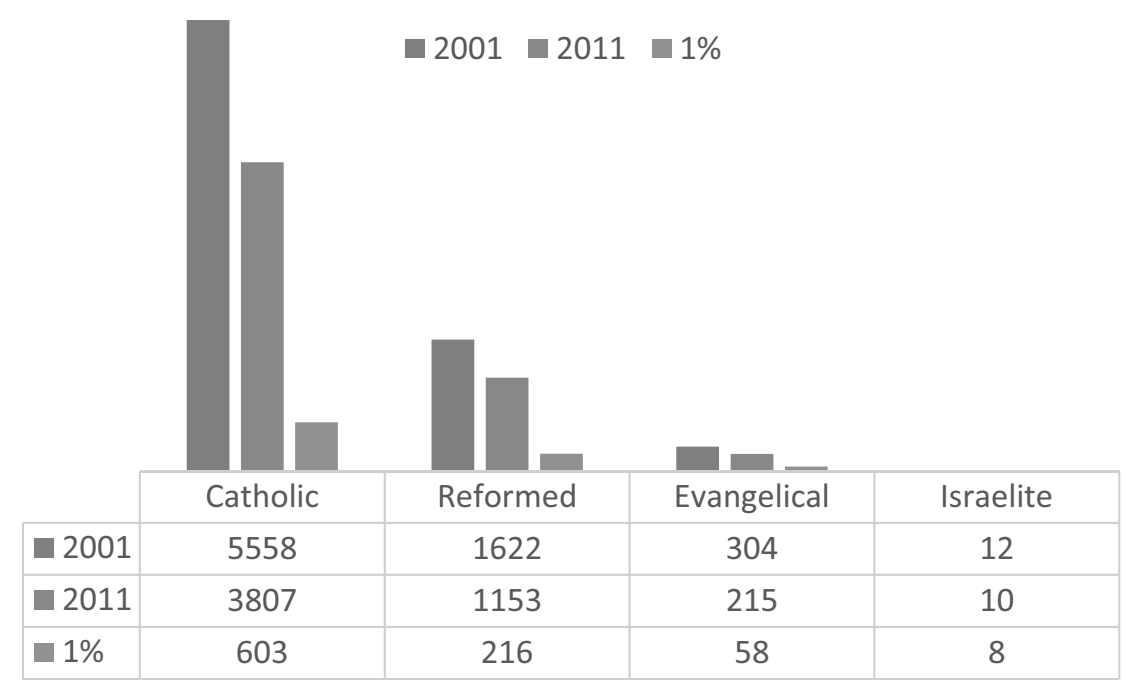

Diagram 1. Census in 2001, 2011 and the declaration of 1\% for historic churches, 2014

Source: http://www.ksh.hu/nepszamlalas/tablak_vallas (access: 24.05.2016). 
This diagram shows the latest data, that is, the data of the two most recent censuses from 2001 and 2011, as well as the 1\% tax declarations for churches in 2014. The census shows it clearly that adherence to the three great historic churches has been dwindling, while the Israelites have maintained the same level of adherence. It is very interesting when there are far fewer people who actually take the trouble to submit a declaration to dedicate $1 \%$ of their taxes to a church - even if we take into account that the census data include children who cannot be taxed, and retired people over the age of 65 . This can actually be seen in the case of all three major Christian churches. The Israelite community is, again, an exception: not counting young people under the age of 25 , we see that they support their community in a disciplined way, and dedicate the $1 \%$ of their taxes to the Israelite community.

Let us move on now to the non-historic denominations, which include Faith Church, Krishna Consciousness, and the Baptist Church, whose charitable organizations I have already mentioned. In their case, we see quite the opposite of what we have seen so far; that is, according to census data, they have been increasing the number of their followers, and even more intriguing is the fact that these churches have been capable of collecting more tax dedications and thereby raising much more money, year by year, while traditional denominations have failed to do so. This has clearly demonstrated their ability to solicit from donors for helping others: in fact, they seem to understand how to communicate with society, and they represent their messages more courageously.

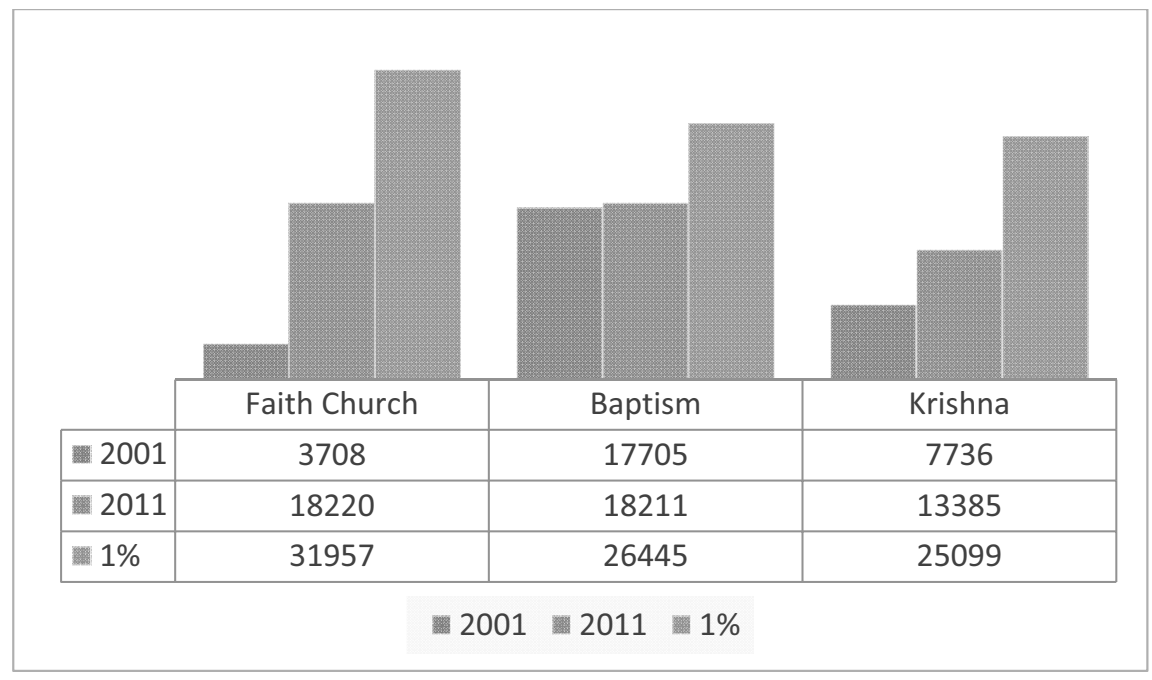

Diagram 2. Census in 2001, 2011 and the dedication of 1\% for non-historic denominations, 2014

Source: http://www.ksh.hu/nepszamlalas/tablak_vallas (access: 24.05.2016). 
In light of the aforementioned data, the new church regulations of 2011 are all the more interesting..$^{18}$ In a nutshell, these regulations replaced liberal church regulations that had been in effect since 1990. While under the previous regulations over 300 churches were registered, new law recognized only a total of 31 churches; the rest were downgraded by the Hungarian parliament as associations engaged in religious activities. There were heated debates, and in the end, it was decided that rendering social services by the organization is indispensable when the latter applies for being awarded the status of a church. In other words, the legislator expressed that it expected these churches to be its partners in the performance of social services; it is not sufficient for them to be engaged in religious activities. ${ }^{19}$ This way, they were 'obliged' to take part in rendering social services. And the circle is closed here, since the more social services this small circle of churches will carry out, the more they can stress that their activities are needed in Hungarian society. This, in turn, will strengthen them further in their position as churches, which, of course, involves budgetary financing of their social services. The empirical study also found that the performance of charities by churches was entirely a matter of state budget, so it was predictable from year to year; private donations or their lack thereof play no particular role, given that they were dwarfed in comparison to state funding. Moreover, the biggest charities, such as the Maltese Charity Service, or the Catholic Caritas, can work without volunteers. One might say that the state outsources tasks, and is looking for partners who are present on the long run - and the churches are ideal partners for this.

There remains the really intriguing question of whether society is at ease with this presence. That is to say, are there a social expectations and acceptance for the presence of churches and quasi-church organizations, for example, in the field of social care - or is this still under discussion?

Let us look first at the issue of social care. Since the regime change, several studies have pointed out that Hungarian society regards it as a primary task of the churches to participate in social assistance, namely to care of the elderly, the homeless, those who are unable to work, the sick, and to be committed to acts of charity. ${ }^{20}$ The research carried out mainly in sub-regions reveals that the churches' social services have been efficiently expanded, so in those small communities where the local government could not easily take up the business of rendering social services due to its lack of resources, the nonobligatory social work activities have been taken over by the locally active churches. These religious organizations and individuals were willing to create their organizations to support the poor. They also were willing to be present as employers, that is, to provide jobs for those who were on the edge of poverty. ${ }^{21}$ By doing so, they manage to success-

18 Act CCVI of 2011, on freedom of conscience and religion, and on legal status of denominations and religious communities.

19 G. Schweitzer, Az egyházakra vonatkozó szabályozás alakulása [The Regulations of Religous Organizations], A. Szalai (ed.), MTA Law Working Papers, Budapest 2014, p. 44.

20 B. Valentényi-Szilágyi, Az egyházak közszolgáltatásokban játszott szerepe [The Role of Denominations in Public Services] [in:] L. Pribula (ed.), A jogalkalmazás vitatott területei - vallásszabadság és egyházjog [Controversial Fields of Dispensation of Justice], Debrecen 2015, pp. 148-166 and p. 155.

21 T. Virág, Közfoglalkoztatás és idősgondozás - szegénységre adott válaszok egy alföldi kisvárosban és tanyavilágban [Public Employment and Home Care - Responses to Poverty in a Small Town and Boonies of Great Hungarian Plain], "Esély" 2014, Vol. 1, pp. 45-63 and p. 53. 
fully integrate their workforce and service recipients in their church, along with their families. Churches consider this to be a social manifestation of the gospel.

Diagram 3. The increased role churches in social care, in percentage 2008-2013

\begin{tabular}{|l|c|c|c|c|}
\hline & $\begin{array}{c}\text { Nurseries/crèche } \\
\text { facilities }\end{array}$ & Nanny services & $\begin{array}{c}\text { Social dining } \\
\text { services }\end{array}$ & Home care \\
\hline $\mathbf{2 0 0 8}$ & 0 & 0 & 1,5 & 2 \\
\hline $\mathbf{2 0 1 3}$ & 2 & 10 & 21 & 46 \\
\hline Growth & $\mathbf{2}$ & $\mathbf{1 0}$ & $\mathbf{1 9 , 5}$ & $\mathbf{4 4}$ \\
\hline & $\begin{array}{c}\text { Wintertime } \\
\text { warming } \\
\text { shelters }\end{array}$ & Soup kitchens & $\begin{array}{c}\text { Permanent and } \\
\text { provisional ca- } \\
\text { tering }\end{array}$ & $\begin{array}{c}\text { Daytime care } \\
\text { institutions }\end{array}$ \\
\hline $\mathbf{2 0 0 8}$ & 7,7 & 13 & 19 & 4,5 \\
\hline $\mathbf{2 0 1 3}$ & 12,7 & 17 & 26 & 12 \\
\hline Growth & $\mathbf{5}$ & $\mathbf{4}$ & $\mathbf{7}$ & $\mathbf{7 , 5}$ \\
\hline
\end{tabular}

Source: Központi Statisztikai Hivatal [Central Statistical Institute].

This tables map the trends that have prevailed in the field of social services in recent years; it shows the increase in the institutional and supply system of churches. If we examine the social services indicated here, we can see that some of them do not require a higher school education or estates.

Typically, these services include care for the elderly, where the role of the churches in the social sector is the highest: they cover $46 \%$ of domestic assistance; followed immediately by long-term residential housing; temporary accommodation in social institutions, in $26 \%$; and then social catering in $19 \%$. For example, let us see the number of crèche facilities or nurseries, day shelters and soup kitchens among the managed institutions. In 2008 , there was not even a single nursery run by a church, while they already managed eight daytime shelters. Both numbers rose to 15 by 2013. The number of soup kitchens in church management doubled, from 5 to 9 . As we have seen in the case of crèche facilities, this was not the churches' target age group in 2008 for some reason, as the churches didn't use to have a single family day care. However, this changed by 2013: by that year, they had obtained a license to accommodate a total of 810 children. The number of recipients of social catering managed by churches grew twentyfold, while home care increased more than 50 times.

In addition to the social sector, the same trend can be observed elsewhere, so let us look at the protection of children, which includes children's homes and the foster care network. ${ }^{22}$ The large-scale advance of churches here is mainly due to financial reasons. Unlike churches, the foundations that were managing bodies did not receive supplemen-

22 I. Szurovecz, Óriásléptekkel tarol az egyház a gyermekvédelemben [Gigantic Expansion of Denominations in Protection of Children], http://abcug.hu/oriasleptekkel-tarol-az-egyhaz-gyerekvedelemben/ (access: 25.05.2016). 
tary per capita funding, so their position became untenable years ago. They found a solution, though: joining a church which functioned as a maintaining body, which they could work together with, and this way they could get their supplementary per capita funding. 'Fészek' Child Protection Association could preserve its professional and organizational autonomy at the price of joining the church as an umbrella organization. Obviously, this is visible in the statistics too, namely, although foundations were the managing bodies in 2009 , those managements were taken over by churches in 2010. By the way, supplementary per capita funding varies each year, but it is still absolutely necessary. For example, in 2015 , the supplementary funding that churches received amounted to $75 \%$ of basic per capita funding.

Civil and ecclesiastical managing bodies are not equal competitors, as the latter, by means of the supplementary per capita funding, can provide better services. Moreover, their standard of service is higher: they are more caring, they carry out inspections more frequently, but are also more helpful than others. The number of the church-related managing bodies may still increase by merger or take-over when foster parents cross over to a church-related managing body; and building a new network is also a possible. For example, the Reformed Church chose this latter option in the poorest regions. This solution has the advantage that it does not generate conflict of interests, reaches new players, and is capable of professional innovations.

Churches generally expect foster parents to participate in the church events along with their foster children, and to raise them in a religious fashion. This is in line with the politicians' statements, who often express that churches and the state must work together.

Before I close, I would like to review the main points of my presentation. There is an exemplary tradition of civic cohesion in Hungary, including initiatives on religious grounds, but its efficacy depends on the ability of organizations to solicit from donors in order to help others. Without this ability, churches and their civil society organizations merely depend on the state budget. Charity and social objectives are the best calls to activate society, which has been recognized by churches and quasi-religious organizations.

\section{Bibliography}

Bősze S, „Az egyesületi élet a polgári szabadság...”, Somogy megye egyesületei a dualizmus korában [,Association Movement is the Civic Freedom...”, Associations of Somogy County in Dualism], Kaposvár 1997.

Brunda G., Egyesületek Nógrád Megyében [Associations in Nógrád County], Salgótarján 1993.

Doromby K., A hivek felelössége az evangélizációért [The Responsibility of Believers in Evangelization], "Vigilia" 1980, Vol. 8.

Gianone A., Az Actio Catholica karitativ tevékenysége 1945-1948-ban [The Charity Work of Actio Catholica], Gy. Karczub (ed.), Válogatott tanulmányok [Selected Studies], Budapest 2002, pp. 41-60.

Gyáni G., Kövér Gy., Magyarország társadalomtörténete a reformkortól a második világháborúig [The Social History of Hungary from the Period of Reforms to the $2^{\text {nd }}$ World War], Budapest 2006 . 
Halmai G., Az egyesülés szabadsága. Az egyesülési jog története [Freedom of Association. The History of Right of Association], Budapest 1990.

Jobb S., Egyesületek Magyarországon [Associations in Hungary], "Statisztikai Szemle" 1972, Vol. 12.

Márfi A., Baranya vármegye egyesületei 1867-1914 [Association of Baranya Counties], Pécs 1986.

Mondovics N., A magyar vallási egyesületek múltjáról [The History of Hungarian Denominational Associations], A. Ádám (ed.), PhD Tanulmányok 13., Pécs 2014, pp. 251-268.

Mondovics N., Az önkéntesség és a magánadományozás tíz magyarországi szervezet müködésében [Voluntarism and Philantrophy on Ten Hungarian Organizations], A. Ádám (ed.), PhD Tanulmányok 14., Pécs 2015, pp. 91-118.

Schweitzer G., Az egyházakra vonatkozó szabályozás alakulása [The Regulations of Religous Organizations], A. Szalai (ed.), MTA Law Working Papers, Budapest 2014.

Sebestény I., Az egyesületek számbavételének módszertani problémái a történeti statisztikában [The Methodical Problems of Reviewing Associations in Historical Statistics], "Statisztikai Szemle" 2003, Vol. 4, pp. 373-387.

Szurovecz I., Óriásléptekkel tarol az egyház a gyermekvédelemben [Gigantic Expansion of Denominations in Protection of Children], http://abcug.hu/oriasleptekkel-tarol-az-egyhaz-gyerekvedelemben/ (access: 26.05.2016).

The Holy Bible.

Tóth Á., Önszervezö polgárok. A pesti egyesületek társadalomtörténete a reformkorban [Self-organizer Citizens. The Social History of Associations of Pest in Hungary before 1848], Budapest 2005.

Valentényi-Szilágyi B., Az egyházak közszolgáltatásokban játszott szerepe [The Role of Denominations in Public Services] [in:] L. Pribula (ed.), A jogalkalmazás vitatott területei - vallásszabadság és egyházjog [Controversial Fields of Dispensation of Justice], Debrecen 2015, pp. 148-166.

Virág T., Közfoglalkoztatás és idösgondozás - szegénységre adott válaszok egy alföldi kisvárosban és tanyavilágban [Public Employment and Home Care - Responses to Poverty in a Small Town and Boonies of Great Hungarian Plain], "Esély" 2014, Vol. 1, pp. 45-63.

\section{Streszczenie}

\section{Zmiany roli Kościołów i organizacji religijnych w obszarze zjawiska społecznej samowystarczalności na Węgrzech (1867-2016)}

Opracowanie stawia sobie za cel przegląd najważniejszych trendów dających się odnaleźć w procesie świadczenia usług społecznych przez Kościoły. Na początek zbadano typowe cele, jakie wyznaczały sobie stowarzyszenia religijne w okresie dualizmu, oraz zmiany dające się zaobserwować w działalności sektora cywilnego podczas rządów Horthy'ego. Opracowanie oparte jest na dokonanych przeze mnie w 2014 roku badaniach empirycznych, w których analizowano działalność największych organizacji charytatywnych na Węgrzech. W konkluzji stwierdzono, iż na Węgrzech istniała budująca tradycja rozwoju spójnej obywatelskiej działalności w obszarze charytatywnym. Skuteczność tej działalności zależała od zdolności owych organizacji do zabiegania o pomoc dla potrzebujących.

Słowa klucze: usługi społeczne, organizacje religijne, solidarność, działalność charytatywna. 